\title{
BAGIAN WARIS AYAH DALAM PERSPEKTIF IJTIHAD SHAHABAT DAN PASAL 177 INSTRUKSI PRESIDEN NOMOR : 1 TAHUN 1991 TENTANG KOMPILASI HUKUM ISLAM
}

\author{
Oleh: Ibnu Rusydi, S.H., M.Pd.I. *)
}

\begin{abstract}
ABSTRAK
Pembagian waris Islam diterapkan sebagai upaya pencegahan terjadinya konflik pertikaian dalam keluarga yang dapat muncul akibat rasa ketidakadilan yang dirasakan oleh para ahli waris terhadap bagian masing-masing. Tiap ahli waris diberikan bagian secara proposional dan sesuai tanggung jawab yang diemban. Mengenai bagian waris ayah, di Indonesia terdapat dua perspektif yakni perspektif Shahabat dan pasal 177 Instruksi Presiden Nomor: 1 Tahun 1991 tentang Kompilasi Hukum Islam. Penelitian ini berusaha memaparkan dan membandingkan bagian waris ayah menurut kedua perspektif tersebut.
\end{abstract}

Kata Kunci : bagian waris Ayah, ljtihad Shahabat, Pasal 177 Kompilasi Hukum Islam.

\section{ABSTRACT}

Division of inheritance Islam applied as efforts to prevent conflict in the family disputes that may arise from a sense of injustice felt by the heirs of the respective parts. Each heir is given part proportionately and in accordance responsibilities carried. Regarding the inheritance father. in Indonesia there are two perspectives namely, Companions perspective and Article 177 of Presidential Instruction No. 1 of 1991 on the Compilation of Islamic Law. This study tried to describe and compare the inheritance father according to both perspectives.

Keywords : the inheritance father, ljtihad Companions , Article 177 Compilation of Islamic Law.

\section{Pendahuluan}

Secara garis besar hukum Islam terbagi kepada dua bidang yaitu bidang Ibadah dan bidang Muamalah. Bidang Ibadah mengatur hubungan manusia dengan Allah SWT, meliputi aturan tentang Shalat, Puasa, Zakat, Haji, Nazar dan sebagainya, sedangkan bidang Muamalah mengatur hubungan manusia dengan manusia, seperti nikah, talak, wasiat, waris, jual beli dan sebagainya.

Dasar-dasar hukum kewarisan Islam pun sangat jelas, sehingga menurut al-Shabuni (Muhammad Ali AlShabuni, 2006 ; hal 39) di dalam Syari'at Islam tidak dijumpai hukum-hukum yang diuraikan oleh al-Qur`an al-Karim secara jelas dan terperinci sebagaimana hukum waris, hanya sebagian kecil saja (perihal hukum waris) yang ditetapkan dengan Sunnah dan ljma'.

\footnotetext{
*) Staf Pengajar Fakultas Hukum Universitas Galuh
} 
Puncak perkembangan hukum waris Islam di Indonesia adalah dengan disusunnya Kompilasi Hukum Islam (yang selanjutnya disingkat $\mathrm{KHI}$ ) yang menjadi pedoman bagi masyarakat Islam Indonesia dan Hakim Pengadilan Agama dalam menerima, memeriksa dan memutuskan perkara. $\mathrm{KHI}$ di Indonesia disahkan melalui Instruksi Presiden Nomor 1 Tahun 1991 tanggal 10 Juni 1991. KHI dalam pertimbangan yuridis, berlaku bagi Instansi Pemerintah dan oleh masyarakat yang memerlukannya dapat digunakan sebagai pedoman dalam menyelesaikan masalah-masalah di bidang tersebut.

Instruksi Presiden tersebut ditindaklanjuti dengan Surat Keputusan Menteri Agama RI Nomor 154 Tahun 1991, tanggal 22 Juli 1991 dan disebarluaskan melalui Surat Edaran Direktur Pembinaan Badan Peradilan Agama Islam Nomor 3694/EV/HK.003/AZ/91 tanggal 25 Juli 1991 dengan meminta kepada seluruh Instansi Departemen Agama terutama Peradilan Agama dan Instansi Pemerintah lain yang terkait, untuk menyebarluaskan $\mathrm{KHI}$ dimaksud dan sedapat mungkin menerapkan $\mathrm{KHI}$ disamping peraturan perundangundangan lainnya

Sumber hukum Islam yang qoth'i (pasti) dan disepakati mayoritas Ulama
Syafi'iyah ada empat macam yaitu: alQur`an, Hadis, ljmâ' Ulama, dan Qiyâs. Konsekuensinya, apabila terdapat suatu ketetapan hukum yang bertentangan dengan ke empat sumber hukum Islam tersebut, maka ketetapan hukum tersebut adalah salah dan batal.

$$
\text { Mengenai bagian waris ayah, }
$$
Allah SWT telah menjelaskan dalam Q.S. al-Nisâ' (4) : 11, yang artinya sebagai berikut :

Dan untuk dua orang ibu-bapa, bagi masing-masingnya seperenam dari harta yang ditinggalkan, jika yang meninggal itu mempunyai anak; jika orang yang meninggal tidak mempunyai anak dan ia diwarisi oleh ibubapanya (saja), Maka ibunya mendapat sepertiga; jika yang meninggal itu mempunyai beberapa saudara, Maka ibunya mendapat seperenam. (Departemen Agama Republik Indonesia, 1989 ; hal 116).

Dalam ayat ini dipahami bahwa bagian waris ibu apabila pewaris yang meninggal tidak mempunyai anak, ia mendapat bagian sepertiga. Sementara itu, bagian waris ayah tidak dijelaskan secara tekstual, hanya saja berdasarkan mafhum/yang difahami dari ayat tersebut, bagian waris ayah adalah sisanya (sebesar dua pertiga bagian), 
hal ini karena bagian laki-laki sama dengan bagian dua anak perempuan dengan didasarkan prinsip al-Qur`an yaitu "li al-dzakari mitslu hadzdzi aluntsayain" (bagian seorang anak lelaki sama dengan bagian dua orang anak perempuan).

Karena itu, pada permasalahan bagian ayah dalam warisan, para Shahabat telah bersepakat, bahwa apabila seorang perempuan meninggal dunia dengan meninggalkan ahli waris suami/duda, ibu dan ayah, maka suami mendapat bagian seperdua, seperdua sisanya untuk ibu, sementara itu berdasar ketentuan bahwa ibu mendapat bagian sepertiga dari sisa warisan (sepertiga dari seperdua), maka ayah mendapat bagian dua pertiga dari sisa warisan (dua pertiga dari seperdua).

Meskipun bagian waris ayah telah dijelaskan secara tersurat dan tersirat di dalam al-Quran dan para Shahabat telah bersepakat mengenai ketentuan masalah di atas, akan tetapi di dalam $\mathrm{KHI}$ terdapat pasal yang bertentangan dengan nash al-Qur'an dan ljma' tersebut yaitu pasal 177 Kompilasi Hukum Islam yang berbunyi: "Ayah mendapat sepertiga bagian bila pewaris tidak meninggalkan anak, bila ada anak ayah mendapat seperenam bagian". Pasal ini dijelaskan dengan Surat
Edaran Mahkamah Agung Nomor 2 Tahun 1994 tentang Pengertian Pasal $177 \mathrm{KHI}$, bahwa ayah mendapat sepertiga bagian bila pewaris tidak meninggalkan anak, tetapi meninggalkan suami dan ibu, bila ada anak, ayah mendapat seperenam bagian.

Ketentuan waris menurut pasal $177 \mathrm{KHI}$ ini bukan saja bertentangan dengan nash Al-Quran dan ljma' Shahabat, tetapi juga menimbulkan kerancuan dalam pembagiannya, jikalau memakai metode penghitungan yang dianut oleh Ulama ahli faraidl baik Ulama salaf maupun khalaf, yaitu dengan menetapkan terlebih dahulu asal masalah (AM) yakni perhitungan dengan mencari angka terkecil yang dapat membagi angka penyebut pada bagian ahli waris yang ada. Kerancuan ini disebabkan, karena masih terdapat sisa bagian waris yang belum habis dibagi, sedangkan prinsip dasar pembagian waris adalah harta warisan habis dibagi.

Berdasarkan latar belakang di atas, terdapat permasalahan yakni : 1) Bagaimanakah ketentuan bagian waris ayah menurut ljtihad para Shahabat? 2) Bagaimanakah ketentuan bagian waris ayah menurut pasal 177 Instruksi Presiden Nomor: 1 Tahun 1991 tentang $\mathrm{KHI}$ ? 
Penelitian ini bertujuan untuk mengetahui, memahami, dan menganalisa bagian waris ayah menurut ljtihad Shahabat dan pasal 177 Instruksi Presiden Nomor: 1 Tahun 1991 tentang KHI. Penelitian ini diharapkan dapat memberikan manfaat bagi perkembangan ilmu pengetahuan khususnya hukum waris dalam praktek pembagiannya.

Metode yang digunakan dalam penelitian ini adalah deskriptif komparatif. Winarno, (Winarno Surakhmad, 1998 : hal 143) mengemukakan, deskriptif komparatif yakni penyelidikan deskriptif yang berusaha mencari pemecahan melalui analisa tentang perhubunganperhubungan sebab-akibat, yakni yang meneliti faktor-faktor tertentu yang berhubungan dengan situasi atau fenomen yang diselidiki dan membandingkan satu faktor dengan yang lain.

\section{Tinjauan Pustaka}

Islam sebagai agama samawi mengajarkan hukum kewarisan, di samping hukum-hukum lainnya, untuk menjadi pedoman bagi umat manusia agar terjamin adanya kerukunan, ketertiban, perlindungan dan ketentraman dalam kehidupan di bawah ridha Allah SWT. Aturan hukum kewarisan Islam diturunkan secara berangsur-angsur sesuai dengan kebutuhan masyarakat sehingga menjadi suatu sistem hukum kewarisan yang sempurna.

Apabila ahli waris ditinjau dari segi bagian-bagian yang diterima oleh mereka, maka mereka dapat dibedakan kepada:

a. Ahli waris Ashâbu Al-Furûdl, yaitu ahli waris yang menerima bagian yang telah ditentukan dalam alQur'an, seperti seperdua, sepertiga dan sebagainya.

b. Ahli waris Ashâbah, yaitu semua ahli waris yang mendapatkan semua harta warisan apabila sendirian dan mengambil sisa warisan setelah ahli waris Ashâbu Al-Furûdl mengambil bagian mereka, seperti anak lakilaki, ayah.

c. Ahli waris Dzawi Al-Arhâm, yaitu ahli waris yang mempunyai hubungan darah dengan pewaris tetapi mereka bukan termasuk Ashâbu Al-Furûdl dan Ashâbah. Seperti paman dan bibi dari pihak ibu

Sementara itu, bagian waris ayah dijelaskan secara tersurat maupun tersirat dalam QS. al-Nisâ’ (4): 11, yakni sebagai berikut:

1) Ayah mendapat seperenam bagian.

Hal ini ditunjukkan oleh QS. al-Nisâ (4): 11, di mana terdapat 
redaksi yang artinya, "...dan bagi kedua orang tuanya, masing-masing mendapat bagian seperenam dari harta peninggalan, jika orang yang meninggal itu mempunyai anak. Tapi apabila orang yang meninggal itu tidak meninggalkan anak, dan ia mewariskan kepada kedua orang tuanya, maka ibu mendapat sepertiga....".(Departemen Agama Republik Indonesia, Loc. Cit., hal. 116)

Jika diamati, memang ayat tersebut tidak ada pernyataan tersurat yang menyatakan bahwa ayah hanya mendapatkan bagian 1/6 dan juga tidak ada pernyataan yang meniadakan kemungkinan untuk menerima ashabah saja atau menerima $1 / 6$ ditambah dengan ashabah. Akan tetapi, jika ditelusuri sesungguhnya ayat tersebut tergolong yang sudah jelas artinya.

Letak kejelasan ayat tersebut bisa ditelusuri dari alur ayat itu sendiri yang secara rinci mengatakan: ...bagian ayah dan ibu masing-masing 1/6..., ketika menyebutkan masing-masing 1/6, Allah tidak menambahkan klausul apa pun. Hanya saja, ketika Allah kemudian meneruskan dengan klausul: "Tapi apabila orang yang meninggal itu tidak meninggalkan anak, dan ia mewariskan kepada kedua orang tuanya, maka ibu mendapat sepertiga....". Maka jelaslah, bahwa bagian $1 / 6$ itu bagi ayah dan ibu, jika yang meninggal mempunyai anak, sebab jika yang meninggal tidak mempunyai keturunan, Allah juga sudah menetapkan bahwa ayah dan ibunya (jika keduanya masih hidup) dengan ketentuan ibu mendapatkan 1/3 bagian dari harta yang ditinggalkan.

2) Ayah mendapat ashabah

Ayah mendapat ashabah, dasar hukumnya adalah metode dalalah lqtidla' Al-Nash dari QS. alNisa (4): 11 tersebut. Dalâlah lqtidlâ` al-Nash menurut Abdul Wahab Khollaf (Abdul Wahab Khallaf, 1978 ; hal 150) yang artinya sebagai berikut:

Dalâlah lqtidlâ' al-Nash adalah suatu makna (ketentuan) dimana suatu ucapan tidak dapat dipahami sepenuhnya, kecuali dengan mentakdirkan/mengirangirakan makna tersebut, artinya bahwa secara nash alQur an tidak ada lafadz yang menjelaskan makna tersebut, tetapi agar arti suatu ayat dalam nash al-Qur'an dapat dipahami sepenuhnya, maka harus mentakdirkan makna tersebut.

Singkatnya, jika dalam suatu ayat ada dua masalah, yang satu 
dijelaskan secara rinci dan yang lainnya tidak, maka masalah yang diabaikan penjelasannya adalah sesuatu yang bergantung kepada yang masalah telah dijelaskan.

Dengan demikian, maksud redaksi QS. al-Nisâ' (4): 11: “Tapi apabila orang yang meninggal itu tidak meninggalkan anak, dan ia mewariskan kepada kedua orang tuanya, maka ibu mendapat sepertiga....". berdasarkan dalâlah Iqtidlâ' al-Nash adalah bahwa bagian waris ayah adalah sisa (2/3) setelah dikurangi 1/3 bagian untuk ibu.

Pemahaman semacam itu juga bisa dijumpai dalam masalah kasus ghanimah dalam QS. al-Anfal (8): 41 yang artinya sebagai berikut:

Ketahuilah, sesungguhnya apa saja yang kamu peroleh sebagai rampasan perang, maka sesungguhnya seperlima untuk Allah, Rasul, kerabat Rasul, anak yatim, orang-orang miskin, dan ibnussabil, jika kamu beriman kepada Allah dan kepada apa yang kami turunkan kepada hamba Kami (Muhammad) pada hari Furqan, yaitu di hari bertemunya dua pasukan. Allah Maha Kuasa atas segala sesuatu. (Departemen Agama Republik Indonesia, Op. Cit., hal. 267)
Ayat tersebut hanya menyebutkan kelompok yang mendapatkan bagian 1/5 dari harta ghanimah (termasuk di dalamnya Allah dan Rasul-Nya). Sedangkan sisanya (4/5) secara otomatis dapat dipahami bahwa bagian itu diperuntukkan bagi mereka yang ikut dalam peperangan. Hal ini bisa dipahami setelah mencermati penjelasan secara detil mengenai siapa saja yang tergabung dalam kelompok penerima 1/5.

Begitu juga dengan masalah kewarisan ayah dalam hal tidak ada anak, ketika Allah menyebutkan bagian ibu adalah 1/3, maka secara otomatis tidak ada pilihan lain bahwa ayah akan menerima sisanya.

Adapun argumentasi dari hadis Rasulullah yang menjelaskan kedudukan ahli waris Ashâbah adalah seperti yang disebutkan alShuyûthi (Al-Shuyûth, hal 103) mengenai hadis Rasulullah yang artinya sebagai berikut: "Berikanlah harta warisan itu kepada orang yang berhak menerimanya, dan sisanya adalah untuk laki-laki yang lebih dekat".

Hadis ini memberikan pemahaman bahwa harta warisan harus diberikan kepada Ashâbu AlFurûdl (orang-orang yang 
mendapatkan bagian pasti) sesuai dengan bagiannya, kemudian jika terdapat sisa, maka sisa harta warisan harus diberikan kepada kerabat laki-laki yang lebih dekat kepada pewaris, dan ayah termasuk kerabat laki-laki yang lebih dekat kepada pewaris.

\section{Pembahasan}

3.1. Ketentuan Bagian Waris Ayah Menurut ljtihad Shahabat

Shahabat adalah manusia yang hidup seperiode dengan Rasulullah dan iman dan membenarkan ajarannya. Dalam memahami permasalahan, tentunya mereka tidak lepas dari petunjuk al-Qur'an dan petunjuk Rasulullah melalui hadisnya. Bila terdapat permasalahan yang tidak dijelaskan oleh keduanya, mereka senantiasa mencari jawaban atas permasalahan dengan menganalogikan ayat atau hadis, maupun dengan ijtihad yang spirit dan esensinya tidak keluar dari ketentuan al-Qur’an dan hadis.

Terkait dengan bagian waris ayah, Shahabat memahami bahwa ayah termasuk ahli waris Ashâbu Al-Furûdl, sebab ia mendapat bagian seperenam (1/6) jika pewaris mempunyai anak, khususnya anak laki-laki, seperti dijelaskan dalam QS. al-Nisa' (4): 11, dan ia termasuk pula ahli waris Ashâbah, sebab ia bisa mendapat semua harta warisan apabila sendirian dan mengambil sisa warisan jikalau terdapat sisa, dan ia merupakan ahli waris Ashâbu Al-Furûdl sekaligus menjadi ahli waris Ashâbah, jika ia mewarisi bersama dengan anak perempuan.

Relevan dengan hal di atas, Muhammad 'Uwaidah menjelaskan pendapat para Shahabat sebagai berikut: (Muhammad 'Uwaidah, 2007 : hal 521)

Dalam pembagian warisan, seorang ayah mempunyai tiga kemungkinan:

1. Memperoleh 1/6 menurut hitungan yang telah ditentukan, jika bersamanya terdapat ahli waris laki-laki dari garis lurus ke bawah.

2. Mendapat bagian warisan menurut ketentuan yaitu $1 / 6$ dan sekaligus mendapatkan bagian ashâbah (sisa), jika bersamanya ada ahli waris perempuan dari garis lurus ke bawah (anak perempuan atau anak perempuan dari anak laki-laki).

3. Mendapatkan warisan dengan jalan ta'síb saja (sisa warisan) yaitu ketika tidak adanya far'u warits (keturunan) dimana dia memperoleh sisa warisan setelah Muhammad 'Uwaidah, Fiqh Wanita Terjemah Al-Jami' Fii Fiqhi An-Nisaa, Pustaka AlKautsar, Jakarta Timur, 2007, hal. 521. mengambil 
bagiannya atau ia mengambil seluruh warisan jika tidak ada Ashâbu Al-Furûdl.

Untuk lebih mudah dipahami bagian waris ayah menurut ijtihad Shahabat, berikut ini diuraikan bagian waris ayah beserta contoh kasus dalam pembagian waris.

1) Memperoleh $1 / 6$ (seperenam)

Jika seseorang meninggal dunia dengan meninggalkan ahli waris yang terdiri dari anak laki-laki, janda dan ayah, dengan meninggalkan harta warisan sebesar Rp. 24.000.000,-. Maka si janda berdasarkan ketentuan al-Qur'an mendapatkan 1/8, karena adanya ahli waris garis lurus ke bawah, sementara si ayah menurut ketentuan al-Qur'an mendapatkan 1/6, karena adanya anak laki-laki. Adapun sisanya diberikan kepada anak laki-laki menurut hitungan ashabah, asal masalah (AM) pada kasus ini adalah 24 dan hasilnya adalah sebagai berikut:

\begin{tabular}{|c|c|c|c|c|}
\hline $\begin{array}{c}\text { Ahli } \\
\text { waris }\end{array}$ & Bag & $\begin{array}{c}\text { AM } \\
24\end{array}$ & $\begin{array}{c}\text { Harta Peninggalan } \\
\text { : AM = Nilai } \\
\text { Persaham }\end{array}$ & $\begin{array}{c}\text { Penerimaan } \\
\text { (Rp.) }\end{array}$ \\
\hline Janda & $1 / 8$ & 3 & X Rp.1.000.000,- & $3.000 .000,-$ \\
\hline Bapak & $1 / 6$ & 4 & X Rp. 1.000.000,- & $4.000 .000,-$ \\
\hline Anak Ik Sisa & 17 & X Rp. 1.000.000,-- & $17.000 .000,-$ \\
\hline \multicolumn{1}{r|}{} & 24 & X Rp. 1.000.000,- & $24.000 .000,-$ \\
\cline { 2 - 5 }
\end{tabular}

2) Mendapat $1 / 6$ dan ashâbah

Ayah mendapat bagian seperenam sekaligus mendapat ashâbah adalah ketika ia mewarisi harta warisan bersama dengan anak perempuan atau lebih. $\mathrm{Hal}$ ini mengingat bahwa ayah tidak mungkin hanya diberi bagian seperenam, karena di samping ia menerima bagian yang telah ditentukan di dalam al-Qur`an, ia juga termasuk ahli waris penerima ashâbah yang dapat menghalangi semua ahli waris selain anak dan ibu. Meskipun demikian, ayah juga tidak mungkin diberikan ashâbah secara lansung, karena ada anak (perempuan) di mana berdasarkan petunjuk nash al-Qur`an, ayah harus menerima bagian 1/6 (seperenam).

Dalam menghadapi persoalan ini, Shahabat berijtihad dengan mengambil jalan tengah, yaitu dengan memberikan bagian 1/6 (seperenam) terlebih dahulu kepada ayah. Jika setelah itu masih ada harta yang tersisa, maka sisa tersebut harus diberikan kepada ayah (tanpa melalui proses radd kepada seluruh ahli waris selain kepada suami atau istri).

Tindakan seperti itu diberlakukan mengingat ayah ketika menerima secara ashâbah, ada kemungkinan tidak mendapatkan warisan jika harta semuanya telah dihabiskan oleh ahli waris penerima 
bagian pasti, atau karena berdasarkan komposisi ahli waris yang ada, terpaksa diberlakukan 'aul. Oleh sebab itu, tindakan memberikan ayah $1 / 6$ bagian (seperenam) terlebih dahulu, manakala ada anak perempuan merupakan perlindungan dari kemungkinan ayah tidak mendapatkan warisan sama sekali.

Untuk lebih jelas bahwa ayah mendapatkan bagian $1 / 6$ dan ashâbah, dapat dilihat pada contoh kasus sebagai berikut: Seseorang meninggal dunia dengan meninggalkan ahli waris yang terdiri dari: seorang anak perempuan, duda, dan bapak dengan harta warisan sebesar Rp12.000.000,-, maka seorang anak perempuan mendapat seperdua, duda mendapat 1/4 dan ayah mendapatkan 1/6 dan sisa, cara penghitungannya adalah:

\begin{tabular}{|c|c|c|c|c|}
\hline $\begin{array}{c}\text { Ahli } \\
\text { waris }\end{array}$ & Bag & $\begin{array}{c}\text { AM } \\
12\end{array}$ & $\begin{array}{c}\text { Harta Peninggalan } \\
\text { : AM = Nilai } \\
\text { Persaham }\end{array}$ & $\begin{array}{c}\text { Penerimaan } \\
\text { (Rp.) }\end{array}$ \\
\hline Anak pr & $1 / 2$ & 6 & X Rp. 1.000.000,- & $6.000 .000,-$ \\
\hline Duda & $1 / 4$ & 3 & X Rp. 1.000.000,- & $3.000 .000,-$ \\
\hline Bapak & $\begin{array}{c}1 / 6+ \\
\text { sisa }\end{array}$ & $1+2$ & X Rp. 1.000.000,- & $3.000 .000,-$ \\
\hline
\end{tabular}

3) Mendapat warisan dengan jalan ta'síb (sisa warisan)

Ketika pewaris tidak mempunyai keturunan, dan ayah mendapat bagian ashâbah, maka harta warisan pun akan terbagi habis dan rasa keadilan pun terwujud, hal ini terlihat dalam contoh kasus hanya dua macam, yaitu mendapat $1 / 3$

sebagai berikut: Jika seseorang meninggal dunia dengan meninggalkan ahli waris terdiri dari duda, bapak dan ibu sedangkan harta warisan peninggalan si pewaris/mayyit sebesar $R p$ 54.000.000,- maka bagian masingmasing adalah: duda mendapat 1/2, bapak mendapat ashâbah dan ibu mendapat 1/3 sisa (karena berkumpul dengan ayah dan duda) cara penghitungan adalah:

\begin{tabular}{|c|c|c|c|c|c|}
\hline $\begin{array}{c}\text { Ahli } \\
\text { waris }\end{array}$ & Bag & $\begin{array}{c}\text { AM } \\
6\end{array}$ & $\begin{array}{c}\text { AM } \\
6\end{array}$ & $\begin{array}{c}\text { Harta } \\
\text { Peninggalan : } \\
\text { AM = Nilai } \\
\text { Persaham } \\
\text { (Rp.) }\end{array}$ & $\begin{array}{c}\text { Penerimaan } \\
\text { (Rp). }\end{array}$ \\
\hline Duda & $1 / 2$ & & 3 & $\times 9.000 .000,-$ & $27.000 .000,-$ \\
\hline Ibu & $1 / 3$ & 3 & 1 & $\times 9.000 .000,-$ & $9.000 .000,-$ \\
\hline Bapak & $\begin{array}{c}\text { sisa } \\
\text { sisa }\end{array}$ & 3 & 2 & $\times 9.000 .000,-$ & $18.000 .000,-$ \\
\cline { 3 - 6 } & & 6 & 6 & $\times 9.000 .000,-$ & $54.000 .000,-$ \\
\hline
\end{tabular}

Ketentuan Bagian Waris Ayah Menurut Pasal 177 Instruksi Presiden Nomor: 1 Tahun 1991 Tentang KHI

Pada dasarnya ketentuan bagian ayah menurut pasal $177 \mathrm{KHI}$ bagian jika pewaris tidak mempunyai anak dan $1 / 6$ bagian jika pewaris mempunyai anak.

a. Mendapat bagian 1/3

Ayah mendapat $1 / 3$ bagian, jika pewaris tidak mempunyai anak, adalah menimbulkan suatu 
kontrovesi, sebab di dalam al-Qur`an tidak ada keterangan yang menjelaskan hal tersebut, bahkan ketika ia mendapat 1/3 bagian, maka menimbulkan suatu kerancuan dalam membagi harta warisan, jikalau cara pembagiannya menggunakan metode penghitungan asal masalah (AM), hal ini bisa dilihat dengan contoh sebagai berikut :

Jika seseorang meninggal dunia dengan meninggalkan ahli waris terdiri dari duda, bapak dan ibu sedangkan harta warisan sebesar $\mathrm{Rp}$ 6.000.000,- maka bagian masingmasing menurut ketentuan $\mathrm{KHI}$ adalah, duda mendapat 1/2 (pasal 179), bapak mendapat $1 / 3$ (pasal 177), dan ibu mendapat $1 / 3$ sisa (pasal 178 (2)). Adapun cara penghitungan pembagiannya dengan cara :

\begin{tabular}{|c|c|c|c|c|}
\hline $\begin{array}{l}\text { Ahli } \\
\text { waris }\end{array}$ & Bag & $\begin{array}{c}\text { AM } \\
6\end{array}$ & $\begin{array}{c}\text { Harta } \\
\text { Peninggalan } \\
\text { AM = Nilai } \\
\text { Persaham } \\
\text { (Rp.) }\end{array}$ & $\begin{array}{c}\text { Penerimaan } \\
\text { (Rp.) }\end{array}$ \\
\hline Suami & $1 / 2$ & 3 & X 1.000.000,- & 3.000.000, \\
\hline Bapak & $1 / 3$ & 2 & X 1.000.000,- & 2.000.000,- \\
\hline Ibu & $\begin{array}{c}1 / 3 \\
\text { sisa }\end{array}$ & 0,33 & X 1.000.000,- & 330.000 \\
\hline & & 5,33 & X 1.000.000,- & 5.330 .000 \\
\hline
\end{tabular}

Berdasarkan penghitungan metode AM terdapat dua masalah yaitu : 1) terdapat sisa warisan yaitu Rp. 670.000,- sedangkan dalam warisan harta harus habis dibagi; 2) bagian ibu, bukan setengah bagian bapak.

Contoh lain yaitu bila seseorang meninggal dunia dengan meninggalkan ahli waris terdiri dari seorang anak laki-laki, janda, ayah dan ibu dengan meninggalkan harta warisan sebesar Rp. 48.000.000,-Maka berdasarkan ketentuan pasal $180 \mathrm{KHI}$, si janda mendapatkan 1/8 bagian, karena pewaris meninggalkan anak laki-laki, sementara si ayah menurut ketentuan pasal $177 \mathrm{KHI}$ mendapatkan $1 / 6$ bagian, karena adanya anak laki-laki. Sedangkan ibu menurut pasal $176 \mathrm{KHI}$ mendapatkan 1/6 bagian, adapun sisanya diberikan kepada anak laki-laki. Asal masalah (AM) pada kasus ini adalah 24 dan hasilnya adalah sebagai berikut :

\begin{tabular}{|c|c|c|c|c|}
\hline $\begin{array}{c}\text { Ahli } \\
\text { waris }\end{array}$ & Bag & $\begin{array}{c}\text { AM } \\
24\end{array}$ & $\begin{array}{c}\text { Heninggalan : } \\
\text { AM = Nilai } \\
\text { Persaham } \\
\text { (Rp.) }\end{array}$ & $\begin{array}{c}\text { Penerimaan } \\
\text { (Rp.) }\end{array}$ \\
\hline Janda & $1 / 8$ & 3 & $\times 2.000 .000,-$ & $6.000 .000,-$ \\
\hline Bapak & $1 / 6$ & 4 & $\times 2.000 .000,-$ & $8.000 .000,-$ \\
\hline Ibu & $1 / 6$ & 4 & $\times 2.000 .000,-$ & $8.000 .000,-$ \\
\hline Anak Ik & Sisa & 13 & $\times 2.000 .000,-$ & $26.000 .000,-$ \\
\hline & & 24 & $X 2.000 .000,-$ & $48.000 .000,-$ \\
\cline { 3 - 5 } & & &
\end{tabular}

b. Mendapat Seperenam

Jika seseorang meninggal dunia dengan meninggalkan ahli waris yang terdiri dari seorang anak perempuan, duda dan ayah dengan meninggalkan harta warisan sebesar Rp. 36.000.000,- Maka berdasarkan 
ketentuan pasal $176 \mathrm{KHI}$, seorang anak perempuan mendapatkan $1 / 2$ bagian, sedangkan menurut pasal $180 \mathrm{KHI}$, si duda mendapatkan $1 / 4$ bagian, karena pewaris meninggalkan anak, sementara si ayah menurut ketentuan pasal 177 $\mathrm{KHI}$ mendapatkan 1/6 bagian, karena adanya anak. Asal masalah (AM) pada kasus ini adalah 12 dan hasilnya adalah sebagai berikut :

\begin{tabular}{|c|c|c|c|c|}
\hline $\begin{array}{c}\text { Ahli } \\
\text { waris }\end{array}$ & Bag & $\begin{array}{c}\text { AM } \\
12\end{array}$ & $\begin{array}{c}\text { Peninggalan : } \\
\text { AM = Nilai } \\
\text { Persaham }\end{array}$ & Penerimaan \\
\hline $\begin{array}{c}\text { Anak } \\
\text { Pr }\end{array}$ & $1 / 2$ & 6 & $\times 3.000 .000,-$ & $18.000 .000,-$ \\
\hline Duda & $1 / 4$ & 3 & $\times 3.000 .000,-$ & $9.000 .000,-$ \\
\hline Bapak & $1 / 6$ & 2 & $\times 3.000 .000,-$ & $6.000 .000,-$ \\
\multicolumn{5}{c}{ Dari penghitungan di atas, } \\
\cline { 2 - 5 }
\end{tabular}

terdapat sisa harta warisan sebesar Rp. 3.000.000,- dan KHI tidak menjelaskan sisa harta warisan tersebut akan dikemanakan.

Apabila bapak mewarisi harta warisan bersama dengan anak lakilaki, maka ketentuan bapak mendapatkan 1/6 harta warisan seperti yang digariskan di dalam pasal $177 \mathrm{KHI}$, adalah sesuai dengan ketentuan al-Qur'an maupun ijtihad para Shahabat dan harta warisan akan habis dibagi, hal ini disebabkan terdapat anak laki-laki yang akan mewarisi harta warisan yang sisa. Apabila harta warisan sebesar Rp. 6.000.000,- maka penghitungannya bisa sebagai berikut :

\begin{tabular}{|c|c|c|c|c|}
\hline $\begin{array}{c}\text { Ahli } \\
\text { waris }\end{array}$ & Bag & $\begin{array}{c}\text { AM } \\
6\end{array}$ & $\begin{array}{c}\text { Harta } \\
\text { Peninggalan } \\
: \text { AM = Nilai } \\
\text { Persaham }\end{array}$ & $\begin{array}{c}\text { Penerimaan } \\
\text { (Rp.) }\end{array}$ \\
\hline Bapak & $1 / 6$ & 1 & $\times 1.000 .000,-$ & $1.000 .000,-$ \\
\hline Anak Ik & Sisa & 5 & $\times 1.000 .000,-$ & $5.000 .000,-$ \\
\hline \multicolumn{1}{|c|}{6} & $\times 1.000 .000,-$ & $6.000 .000,-$ \\
\hline
\end{tabular}

Singkatnya, bapak mendapat

1/6 bagian bila bersama dengan anak laki-laki, tidak akan menimbulkan suatu permasalahan, sebab harta warisan akan habis dibagi, akan tetapi akan terdapat suatu masalah, bilamana bapak mendapat $1 / 6$ bagian bersama dengan anak perempuan. Masalah itu adalah: 1) Terdapat sisa warisan; 2) Ketentuan bapak mendapat $1 / 6$ bagian ini bertentangan dengan ljma' Shahabat, sedangkan ljma' yang tertinggi martabatnya berdasarkan empat mahzab (Hanafiah, Malikiyah, Syafi'iyyah dan Hambaliyah) adalah ljma' Shahabat, dan orang-orang yang hidup setelah Shababat tidak boleh menetapkan hukum yang bertentangan dengan ljma Shahabat, dan menurut ljma' Shahabat, ayah mendapat $1 / 6$ bagian dan sisa warisan, bilamana ia bersama dengan anak perempuan.

\section{Kesimpulan}


Hasil penelitian dapat

disimpulkan sebagai berikut :

1. Ketentuan bagian waris ayah menurut ljtihad para Shahabat yang mencakup tiga bagian : 1) Memperoleh 1/6 menurut hitungan yang telah ditentukan oleh alQur`an; 2) Mendapat bagian wari 1/6 dan sekaligus mendapatkan bagian ashâbah, 3) Mendapatkan warisan dengan jalan ta'sib saja (sisa warisan) yaitu ketika tidak adanya far'u warits (keturunan).

2. Ketentuan bagian waris ayah menurut pasal 177 Instruksi Presiden Nomor: 1 Tahun 1991 tentang Kompilasi Hukum Islam adalah mencakup dua bagian, yaitu : 1) mendapat sepertiga bagian bila pewaris tidak meninggalkan anak; 2) Ayah mendapat bagian seperenam, bila pewaris meninggalkan anak.

Sebagian ketentuan bagian waris ayah menurut pasal $177 \mathrm{KHI}$ sudah sesuai dengan ketentuan alQur`an dan Sunnah, yaitu manakala ayah mendapat bagian seperenam, bila pewaris meninggalkan anak. Sedangkan sebagian lagi bertentangan dengan ketentuan alQuran dan Sunnah, yaitu ayah mendapat sepertiga bagian bila pewaris tidak mempunyai anak, sebab di dalam al-Qur`an tidak ada keterangan bahwa ayah mendapatkan bagian sepertiga.

\section{DAFTAR PUSTAKA}

Al-Shabuni, Muhammad Ali (2006) Hukum Waris Dalam Syari'at Islam Disertai Contoh-Contoh Pembagian Harta Pusaka, Bandung: CV Diponegoro.

Al-Shuyûthi, (t.t) Al-Jâmi'u Al-Shogír Juz 1, Indonesia: Daru Ihyầi AlKutubi Al-Arobiyyah.

Departemen Agama Republik Indonesia, (1989) Al-Quran dan Terjemahannya, Semarang: CV. Toha Putra.

Khallaf, Abdul Wahab (1978) IImu Ushûl Al-Fiqh, Kuwait: Dâru AlQolam.

Surakhmad, Winarno (1998) Pengantar Penelitian IImiah Dasar Metode dan Teknik, Tarsito, Bandung.

Uwaidah, Muhammad (2007) Fiqh Wanita Terjemah Al-Jâmi' Fí Fiqhi Al-Nisâ, Jakarta Timur: Pustaka Al-Kautsar. 